HOW TO STUDY LITERATURE

General Editors: John Peck and Martin Coyle

HOW TO STUDY MODERN DRAMA 
IN THE SAME SERIES

How to Study a Novel John Peck

Literary Terms and Criticism John Peck and Martin Coyle

How to Study a Shakespeare Play John Peck and Martin Coyle

How to Begin Studying English Literature Nicholas Marsh

How to Study a Jane Austen Novel Vivien Jones

How to Study a Thomas Hardy Novel John Peck

How to Study a Renaissance Play Chris Coles

How to Study Romantic Poetry Paul O'Flinn

How to Study a Poet John Peck

IN PREPARATION

How to Study a Play Robert Gordon

How to Study a D. H. Lawrence Novel Nigel Messenger

How to Study Chaucer Robert Pope

How to Study Literature: Practical Criticism Martin Coyle 


\title{
HOW TO STUDY MODERN DRAMA
}

\author{
Kenneth Pickering
}

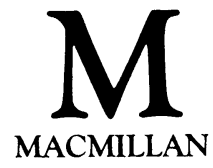


(C) Kenneth Pickering 1988

All rights reserved. No reproduction, copy or transmission of this publication may be made without written permission.

No paragraph of this publication may be reproduced, copied or transmitted save with written permission or in accordance with the provisions of the Copyright Act 1956 (as amended).

Any person who does any unauthorised act in relation to this publication may be liable to criminal prosecution and civil claims for damages.

First published 1988

Published by

Higher and Further Education Division

MACMILLAN PUBLISHERS LTD

Houndmills, Basingstoke, Hampshire RG21 2XS

and London

Companies and representatives

throughout the world

Typeset by Wessex Typesetters

(Division of The Eastern Press Ltd)

Frome, Somerset

British Library Cataloguing in Publication Data

Pickering, Kenneth

How to study modern drama.-- (How to

study literature).

1. English literature-Study and

teaching 2. Drama-Study and teaching

I. Title II. Series

$822^{\prime} .007$ PR625

ISBN 978-0-333-42864-1 ISBN 978-1-349-09129-4 (eBook)

DOI 10.1007/978-1-349-09129-4 


\section{Contents}

General editors' preface vi

Acknowledgements vii

1 Introduction 1

$\begin{array}{lll}2 & \text { First reading } & 7\end{array}$

3 The scene as a unit for study 24

4 Looking at the language of plays 42

5 Tackling different kinds of play 66

6 Practical workshops and drama study $\quad 89$

7 Characters and themes 112

8 Exams and essays $\quad 119$

$\begin{array}{ll}\text { Further reading } & 129\end{array}$ 


\section{General editors' preface}

Everybody who studies literature, either for an examination or simply for pleasure, experiences the same problem: how to understand and respond to the text. As every student of literature knows, it is perfectly possible to read a book over and over again and yet still feel baffled and at a loss as to what to say about it. One answer to this problem, of course, is to accept someone else's view of the text, but how much more rewarding it would be if you could work out your own critical response to any book you choose or are required to study.

The aim of this series is to help you develop your critical skills by offering practical advice about how to read, understand and analyse literature. Each volume provides you with a clear method of study so that you can see how to set about tackling texts on your own. While the authors of each volume approach the problem in a different way, every book in the series attempts to provide you with some broad ideas about the kind of texts you are likely to be studying and some broad ideas about how to think about literature; each volume then shows you how to apply these ideas in a way which should help you construct your own analysis and interpretation. Unlike most critical books, therefore, the books in this series do not simply convey someone else's thinking about a text, but encourage you and show you how to think about a text for yourself.

Each book is written with an awareness that you are likely to be preparing for an examination, and therefore practical advice is given not only on how to understand and analyse literature, but also on how to organise a written response. Our hope is that although these books are intended to serve a practical purpose, they may also enrich your enjoyment of literature by making you a more confident reader, alert to the interest and pleasure to be derived from literary texts.

John Peck Martin Coyle 


\section{Acknowledgements}

THE author wishes to express grateful thanks to Kevin Wood and the cast of Channel Theatre's production of The Birthday Party for many new insights; to Jean and Irene Pickering for their careful work on the manuscript; and to Martin Coyle and John Peck for their seemingly inexhaustible supply of helpful suggestions.

The author and publishers gratefully acknowledge permission to use copyright material granted by the following:

Professor Shelley Frome and the editor of Speech and Drama; Jonathan Cape Ltd for extracts from the works of Wesker; Eyre Methuen Ltd for extracts from plays by Harold Pinter, Shelagh Delaney, Bertold Brecht and Henrik Ibsen; Faber and Faber for an extract from Look Back in Anger; Penguin Plays for extracts from Death of a Salesman. 
For Susannah and Simon 